\title{
Quando l'architettura è illustrazione: la comunicazione del progetto
}

\author{
Giulia Pettoello
}

\section{Abstract}

II presente articolo indaga le illimitate potenzialità dell'illustrazione grafica in ambito architettonico. La comunicazione del progetto costituisce infatti un aspetto in continua evoluzione. II caso studio presentato in questa ricerca riguarda la progettazione relativa a un'area periferica degradata in disuso situata nel quartiere Fuente de San Luis a Valencia, Spagna. In particolare, l'intervento si occupa della progettazione di alloggi collettivi. La sfida è quella di progettare un complesso architettonico, collettivo e sociale, caratterizzato da un'elevata qualità spaziale. La funzione infatti non deve necessariamente, come invece troppo spesso accade, andare a compromettere la qualità abitativa. Verde, spazi comuni e patii a doppia altezza si intersecano per dar luogo a un 'architettura vivente'. Obiettivo del presente lavoro è quello di creare un'illustrazione sintetica in grado di coinvolgere il fruitore. II ruolo della rappresentazione grafica è essenziale per far sì che l'idea del progettista possa essere veicolata al fine di agevolarne la comprensione. La volontà è quella di rendere la narrazione più efficace non solo per i tecnici del settore ma soprattutto per un pubblico non specializzato: la cittadinanza o gli eventuali futuri investitori. L'illustrazione di sintesi realizzata ricopre il ruolo di raccordo tra 'spazio immaginato' e 'spazio costruito' e quindi tra l'idea e la sua successiva realizzazione. L'illustrazione grafica diventa quindi linguaggio essenziale per indagare, raccontare e diffondere l'essenza intrinseca dell'architettura.

Parole chiave

illustrazione, architettura, città, disegno, progetto.

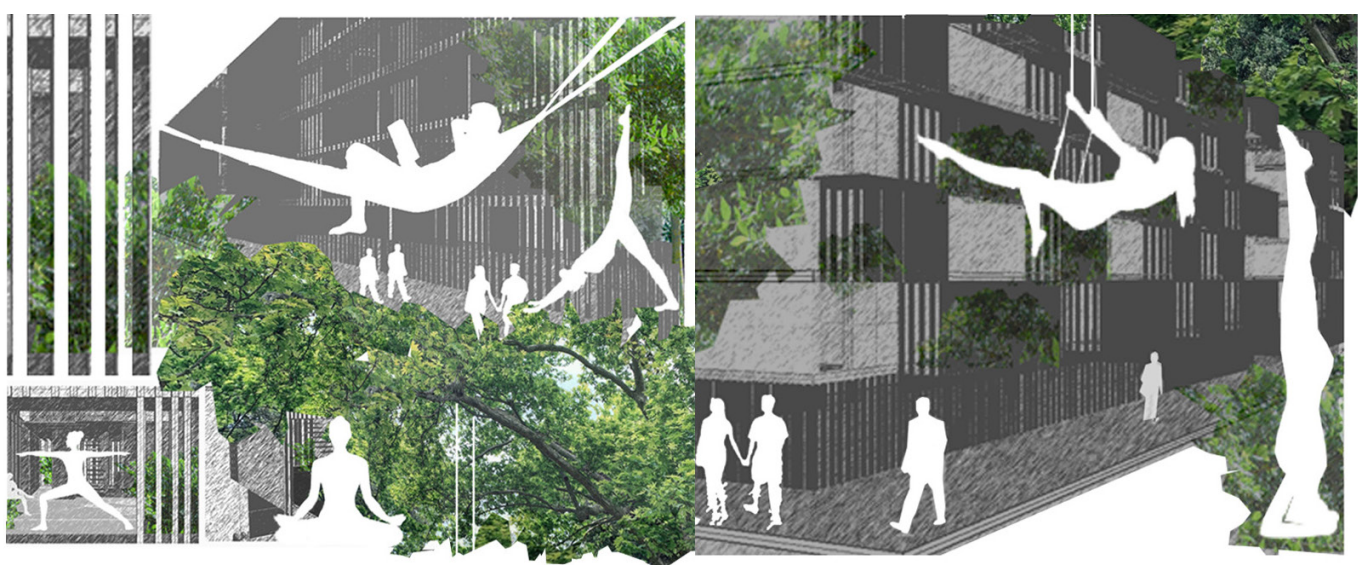




\section{Introduzione}

Disegno tradizionale, disegno digitale, rappresentazione grafica integrata, collage digitale, sono innumerevoli gli strumenti e le modalità per realizzare un'illustrazione grafica. "il sostantivo disegno definisce qualsiasi immagine prodotta da un tracciato lineare eseguito con strumenti come matita, penna, pennello, punta metallica, sanguigna. Deriva dal verbo disegnare, che ha origine a sua volta dal latino designare, un termine che può essere tradotto in molti modi: abbozzare, accennare, alludere, delimitare, tracciare, notare, segnare, imitare, scegliere, ordinare, disporre. Si tratta di significati che indicano sia il semplice abbozzo di qualcosa (una figura o un paesaggio), sia la precisa notazione delle sue caratteristiche (come il suo volume, i colori, il riflesso della luce sulle sue superfici" [I]. Questa definizione rende immediatamente evidente quanto il disegno, e quindi più in generale l'illustrazione grafica, sia complessa e allo stesso tempo estremamente potente. II disegno deve essere quindi inteso non solo come risultato finale ma come strumento per tradurre il pensiero su carta. La connessione tra disegno e pensiero è fortissima. Nel presente articolo il disegno viene interpretato secondo diversi punti di vista, come strumento di progetto, e quindi attraverso la realizzazione di schizzi preliminari e disegni tecnici $2 \mathrm{D}$, come strumento di verifica, e quindi attraverso rappresentazioni volumetriche 3D di studio, e infine come strumento di comunicazione attraverso la realizzazione di immagini di sintesi complessive. "Bisogna disegnare sempre, disegnare con gli occhi se non si può disegnare con la matita. Finchè non farete procedere la riflessione con la pratica, non farete niente di veramente buono" [2]. In particolare, la ricerca si traduce nella realizzazione di diverse illustrazioni grafiche che corrispondono alle diverse fasi del lavoro: schizzi di progetto; schema planimetrico/distributivo; rappresentazioni volumetriche di sintesi relative all'aggregazione delle unità abitative; rappresentazione 2D della distribuzione interna; prospetti e sezioni scala 1:200; assonometrie d'insieme e illustrazione di sintesi del progetto. II disegno risulta quindi essenziale nell'intero iter creativo sia come strumento di progettazione che come mezzo di comunicazione dell'idea di progetto. Obiettivo della ricerca è quello di creare un'illustrazione sintetica in grado di coinvolgere il fruitore. Tale illustrazione infatti riporta delle viste di progetto in cui l'utente viene inserito come protagonista. Alcune delle prospettive realizzate, ad esempio,
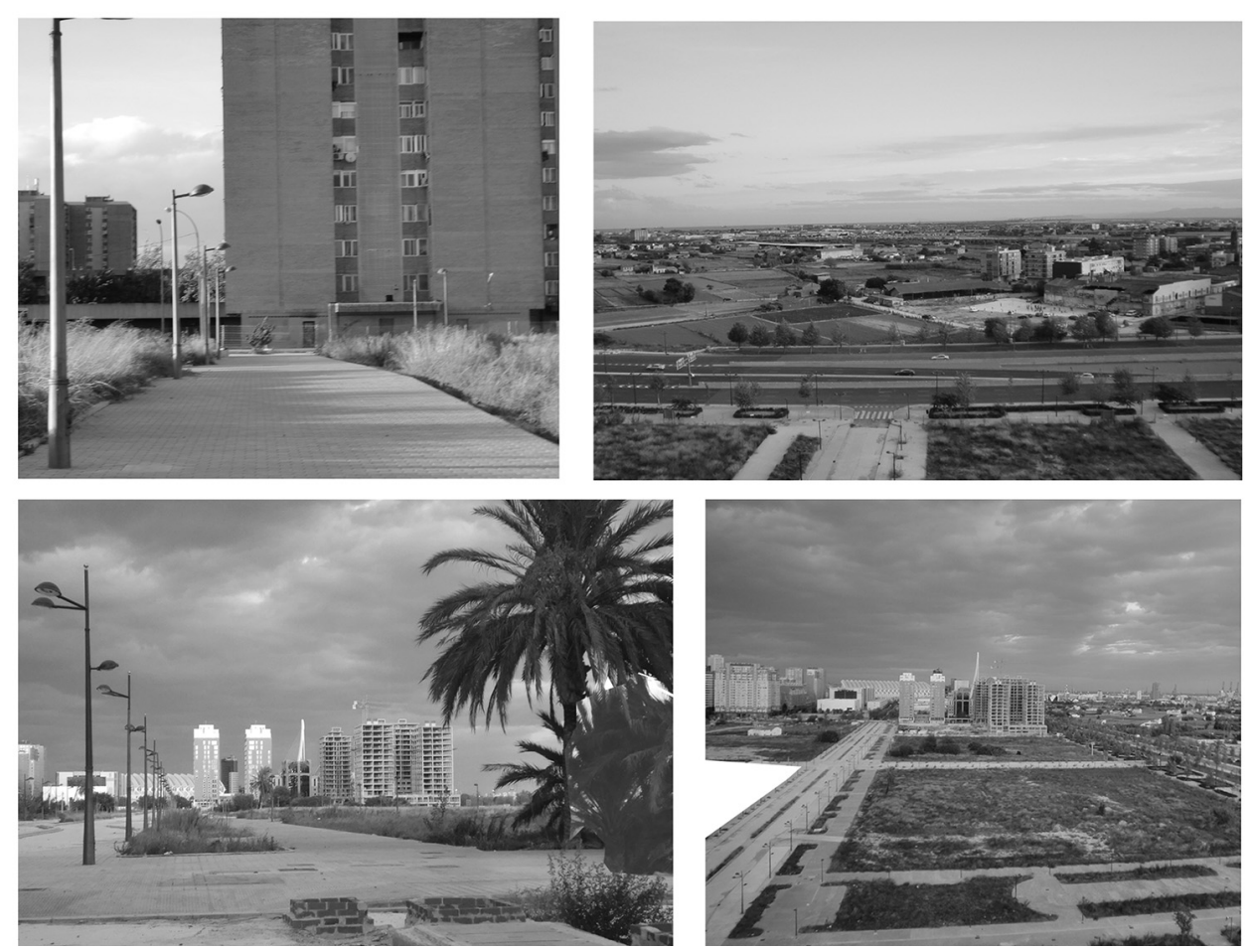
solo ad altezza uomo proprio per dare la possibilità all'utente di potersi 'immaginare' all'interno dello spazio progettato. La tecnica utilizzata è mista: coesistono disegni tradizionali e rappresentazioni realizzate in digitale.

Gli step percorsi nella presente ricerca sono: individuazione di unità residenziali che attraverso un sistema di ripetizione e modularità costruiscono il fronte urbano; definizione dei diversi sistemi di aggregazione delle unità abitative e infine rappresentazione di sintesi. L'obiettivo del progetto architettonico è quello di creare un edifico 'filtro', quindi caratterizzato da un basso impatto visivo e soprattutto dalla presenza di vegetazione al suo interno. Caratteristica principale del presente lavoro è duplice: integrare all'interno dell'architettura stessa il verde e liberare quanto più possibile il suolo trasformandolo in area comune all'aperto e zona verde.

Fig. 2. Fotografie a colori dell'area di progetto (foto di G. Pettoello).
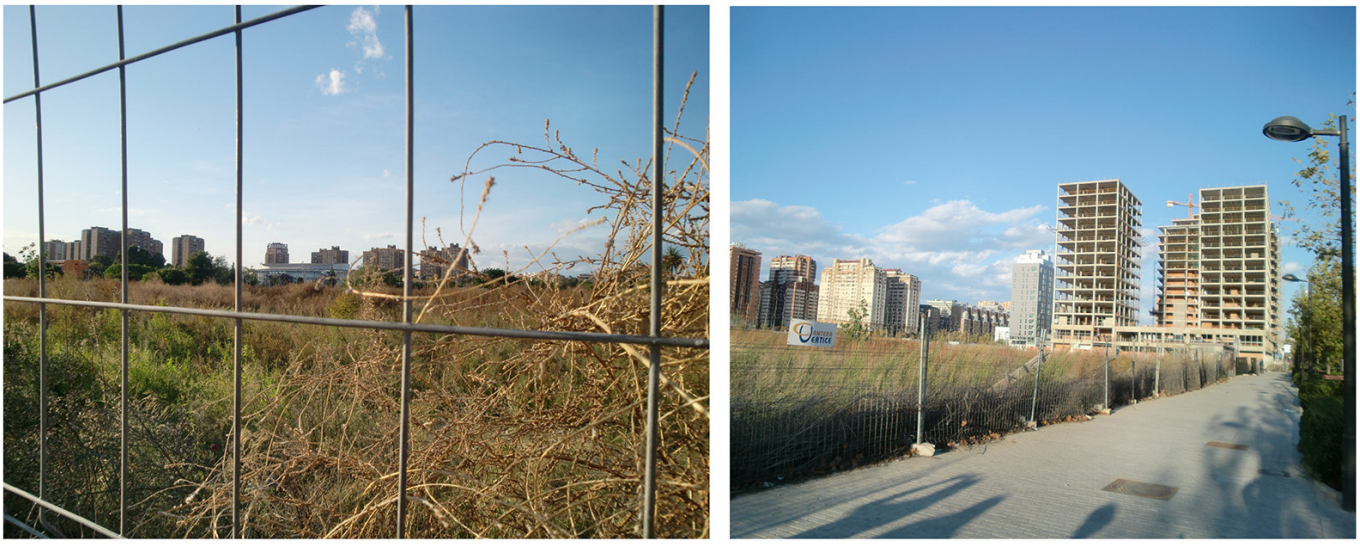

\section{Stato dell'arte}

Tra i diversi casi studio analizzati significativi sono i progetti dell'architetto Stefano Boeri. "Rispetto a questo tipo di architettura si è innescata una vera e propria tendenza internazionale verso il Vertical Foresting" [3]. In particolare, a essere analizzate sono le illustrazioni più significative del progetto. Numerose sono le rappresentazioni nelle quali a essere protagonista è proprio 'l'elemento' verde. II complesso architettonico, infatti, risulta sempre essere messo in secondo piano. Tale scelta grafica è particolarmente incisiva e riesce a esprimere perfettamente l'essenza del progetto.

Altro caso studio particolarmente significativo analizzato è Tbl Msc Komplex [4] di Clark Adam Ter. Anche in questo caso si tratta di 'un'architettura verde'. Interessante è la scelta cromatica che accomuna le diverse rappresentazioni del progetto. L'architettura è sempre rappresentata in scala di grigi per dare invece enfasi all'elemento verde che risulta essere protagonista. Vengono realizzate sia viste d'insieme che di dettaglio ma predominante è la vista altezza uomo proprio per rendere le illustrazioni più 'comunicative'. Interessante è il contrasto che si crea tra le superfici e i volumi architettonici più rigorosi e gli elementi naturalistici più 'fluidi'.

Ulteriore lavoro analizzato è quello del gruppo Sou Fujimoto Architects [5]. Anche in questo caso la palette cromatica di tutte le rappresentazioni prevede la scala di grigi per l'architettura e il verde per tutti gli elementi naturali. Oltre all'utilizzo del monocromatico per quanto riguarda l'architettura significativa è anche la leggerezza del segno e l'introduzione delle ombre, proprie e portate, per dare risalto al costruito. Le illustrazioni risultano quindi particolarmente eleganti e raffinate ma al tempo stesso particolarmente incisive.

Particolarmente significativa è anche la modalità grafica scelta per rappresentare il progetto Gallery of Tsinghua Ocean Center [6]. In questo caso si tratta di schemi assonometrici molto semplici che riescono in pochissimi passaggi a spiegare l'intero complesso iter progettuale. 
Tutti i casi studio precedentemente citati si sono dimostrati particolarmente significativi in quanto particolarmente emblematici della ampia tematica relativa del verde nell'architettura. Il presente articolo indaga in via sperimentale le diverse modalità, tradizionali e integrate, necessarie per illustrare I'architettura verde' e in particolare il caso studio situato nel quartiere spagnolo Fuente de San Luis.

Fig. 3. Definizione del concept: rappresentazioni relative agli schizzi di studio (elaborazione grafica G. Pettoello)
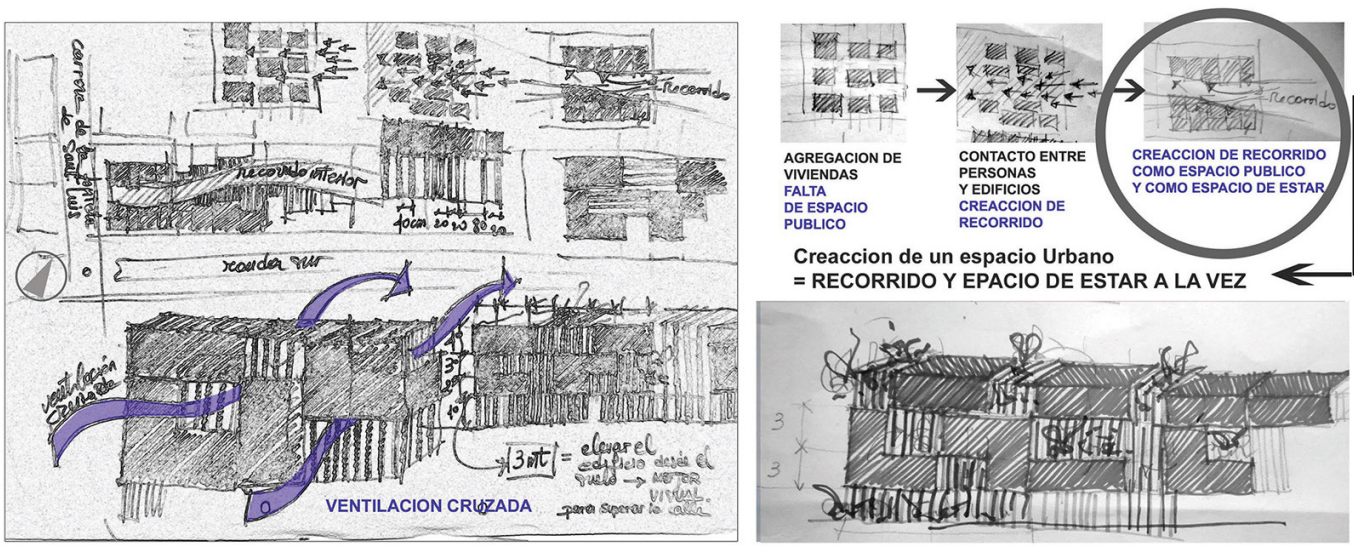

= RECORRIDO Y EPACIO DE ESTAR A LA VEZ
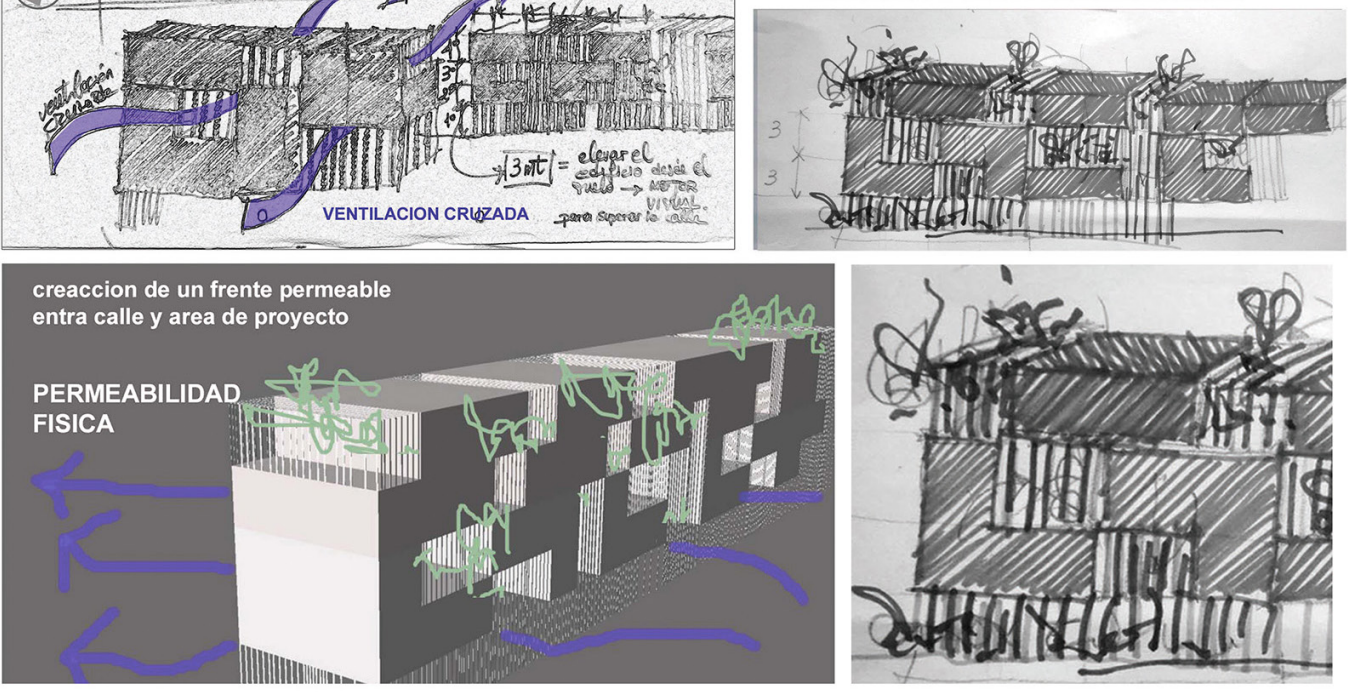

\section{Le fasi progettuali}

Il lavoro presentato è stato svolto secondo fasi successive, tutte interconnesse tra loro. La prima fase ha riguardato il sopralluogo dell'area oggetto di studio. Si tratta del quartiere Fuente de San Louis (fig. I), situato nella periferia valenciana. Tale fase di presa visione del luogo ha previsto anche la realizzazione di una campagna fotografica della particella oggetto di studio (fig. 2). Molto utili, al fine del rilievo fotografico, sono stati i palazzi limitrofi, salendo ai piani alti di questi ultimi è stato infatti possibile fare delle foto dall'alto in modo da comprendere meglio anche varie possibili 'visuali' da poter poi sfruttare in fase progettuale. Dal sopralluogo è risultata evidente la scarsissima qualità architettonica, appunto degli edifici limitrofi all'area di progetto. Palazzi di I0, I 5 piani privi di spazi esterni e tutti molto simili gli uni agli altri. Altro aspetto essenziale risultato evidente è stata la carenza di un'area verde attrezzata, che potrebbe essere realizzata molto facilmente senza necessità dello stanziamento di ingenti somme di denaro. La seconda fase ha riguardato la progettazione del concept. In particolare, quindi, grazie alla realizzazione di schizzi preliminari e rappresentazioni grafiche a mano libera è stato possibile delineare l'idea di progetto (fig. 3). La terza fase ha previsto la realizzazione del 3D di studio (fig. 4). In questa fase la realizzazione di solidi schematici è stata essenziale. La 'maquette digitale' infatti, a differenza della 'maquette fisica' ha il grande vantaggio di poter essere smontata e rimontata costantemente e in tempo reale semplicemente facendo delle copie di back up del volume originale. Tale approccio, particolarmente flessibile e speditivo, ha reso possibile la verifica immediata dell'idea di progetto precedentemente stabilita. L'incastro di 'elementi modulari' con forme e dimensioni diverse ha reso 
possibile al tempo stesso: raggiungere un effetto molto movimentato e al contempo facilmente eseguibile e quindi evitando elementi particolarmente personalizzati che richiederebbero ingenti somme di denaro per la loro realizzazione. Trattandosi infatti di architettura 'pubblica' aspetto essenziale e da tenere costantemente presente è proprio l'ottimizzazione e la sostenibilità economica. La quarta fase ha previsto la realizzazione di rappresentazioni schematiche per la verifica dei volumi (fig. 5). La quinta fase ha riguardato la realizzazione al CAD in 2D delle rappresentazioni in piatta, prospetti e sezioni del progetto (figg. 6-8). In questa fase sono state realizzate anche delle assonometrie per rappresentare la distribuzione degli spazi outdoor (fig. 9). L'ultima fase ha previsto la realizzazione dell'immagine grafica di sintesi: manifesto del progetto, che verrà descritta nel dettaglio successivamente.

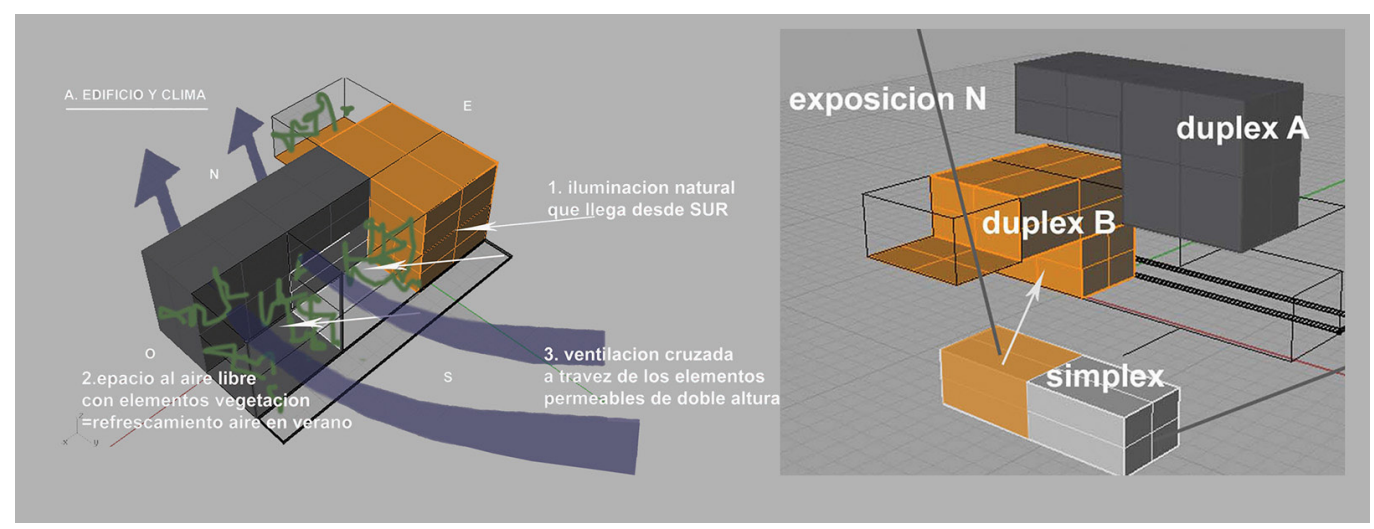

\section{L'illustrazione grafica architettonica}

La sfida è quella attraverso un'unica e singola immagine, 'manifesto di progetto', comunicare la potenza e il valore dell'intero progetto. Prima caratteristica indispensabile di tale rappresentazione è quella di possedere una grande capacità di sintesi. Deve infatti riuscire a comunicare, trasmettere e rendere espliciti molteplici aspetti mantenendo però una estrema chiarezza espressiva. Tra i diversi aspetti da mostrare, sicuramente il più difficile è proprio il valore 'intangibile' che il progetto architettonico proposto porta in quel luogo e a quella collettività. In quanto valore 'intangibile' risulta infatti particolarmente complessa la sua 'traduzione grafica'. In questo caso il 'plus valore' che il progetto offre è proprio la possibilità di ricavare spazi verdi, sia pubblici che privati, capaci di migliorare la qualità della vita dei futuri abitanti. L'attenzione si è posta soprattutto sulla progettazione di piccoli spazi verdi outdoor progettati per ogni singola unità abitativa. Gli spazi outdoor progettati variano per tipologia e dimensione ma hanno in comune la caratteristica di aggiungere qualità alla singola abitazione. Tra le diverse tipologie di spazio verde create si riportano di seguito le principali: balcone, patio a doppia altezza, terrazza parzialmente coperta e terrazza scoperta. Tali spazi progettati per arricchire gli alloggi permettono al loro interno lo svolgimento di numerose attività ludico ricreative, tra le tante si evidenziano le più significative: lettura, yoga, elioterapia e coltivazione del verde e di piccoli orti. L'illustrazione grafica di sintesi, il 'manifesto di progetto', pende proprio questo aspetto come elemento preponderante. Si sceglie quindi di mostrare persone intente a praticare diversi hobby, dai più comuni ai più inusuali, proprio per enfatizzare questo aspetto del progetto. Invece di mostrare piante sezioni e prospetti, elaborati molto tecnici, essenziali ovviamente in fase progettuale, ma poco idonei alla comunicazione, si è scelto di 'costruire' una rappresentazione leggibile da tutti, tecnici ma anche e soprattutto per i non addetti ai lavori come, ad esempio, i cittadini o gli eventuali stakeolders e finanziatori del progetto. Inoltre, per creare una rappresentazione più dinamica si è scelto di selezionare 'viste' differenti quali: prospettive di insieme e di dettaglio per creare una composizione che fosse più possibile esplicativa dell'intero progetto. Tuttavia, 
Fig. 5. Schemi grafici di comunicazione del progetto (elaborazion grafica G. Pettoello)

Fig. 6. Rappresentazione planimetrica del progetto (elaborazione grafica G. Pettoello).

Fig. 7. Rappresentazione 2D CAD delle piante

dell'edificio progettato

(elaborazione grafica $\mathrm{G}$.

Pettoello).
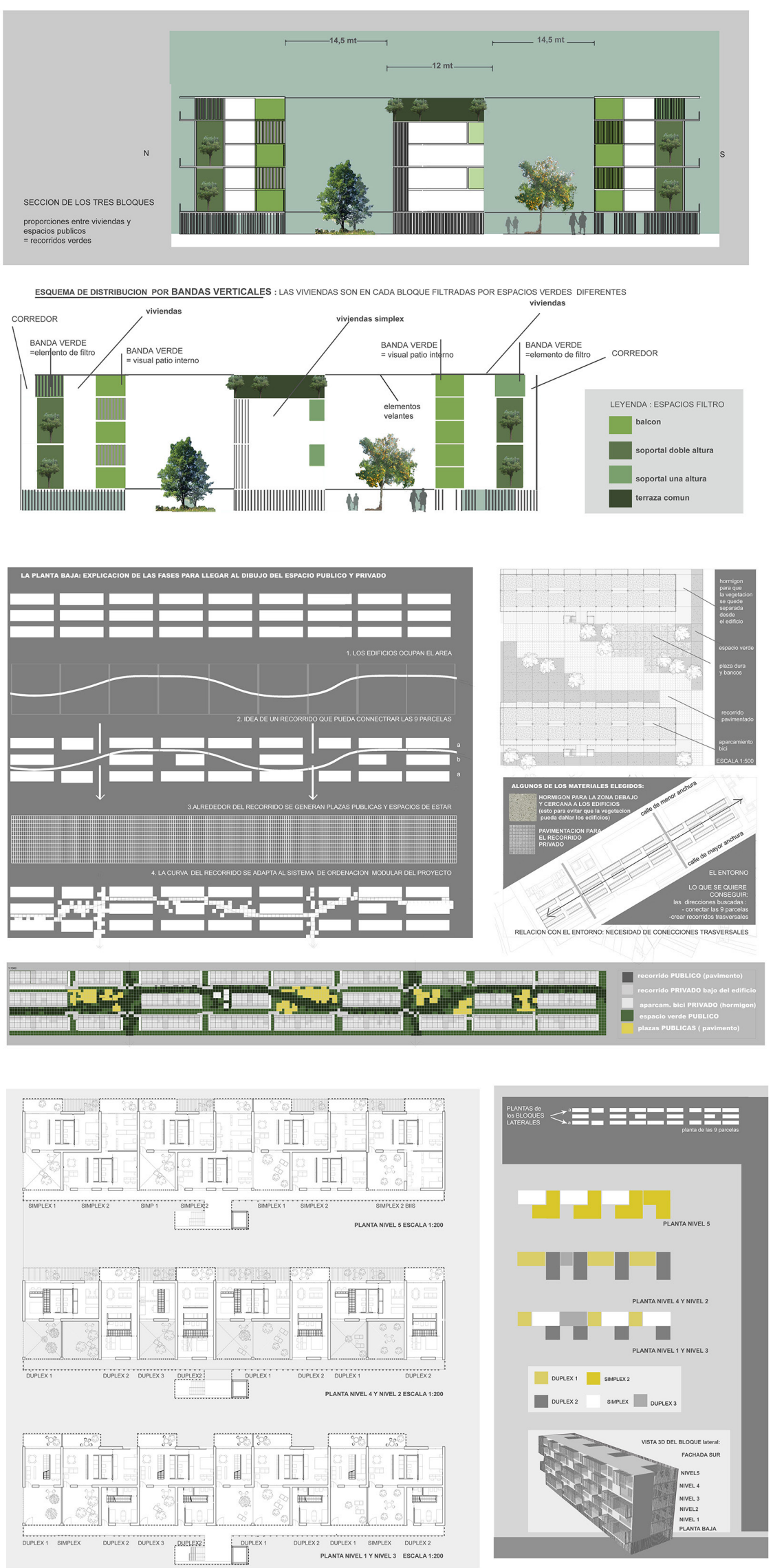
Fig. 8. Rappresentazione 2D CAD dei prospetti dell'edificio progettato (elaborazione grafica G. Pettoello).
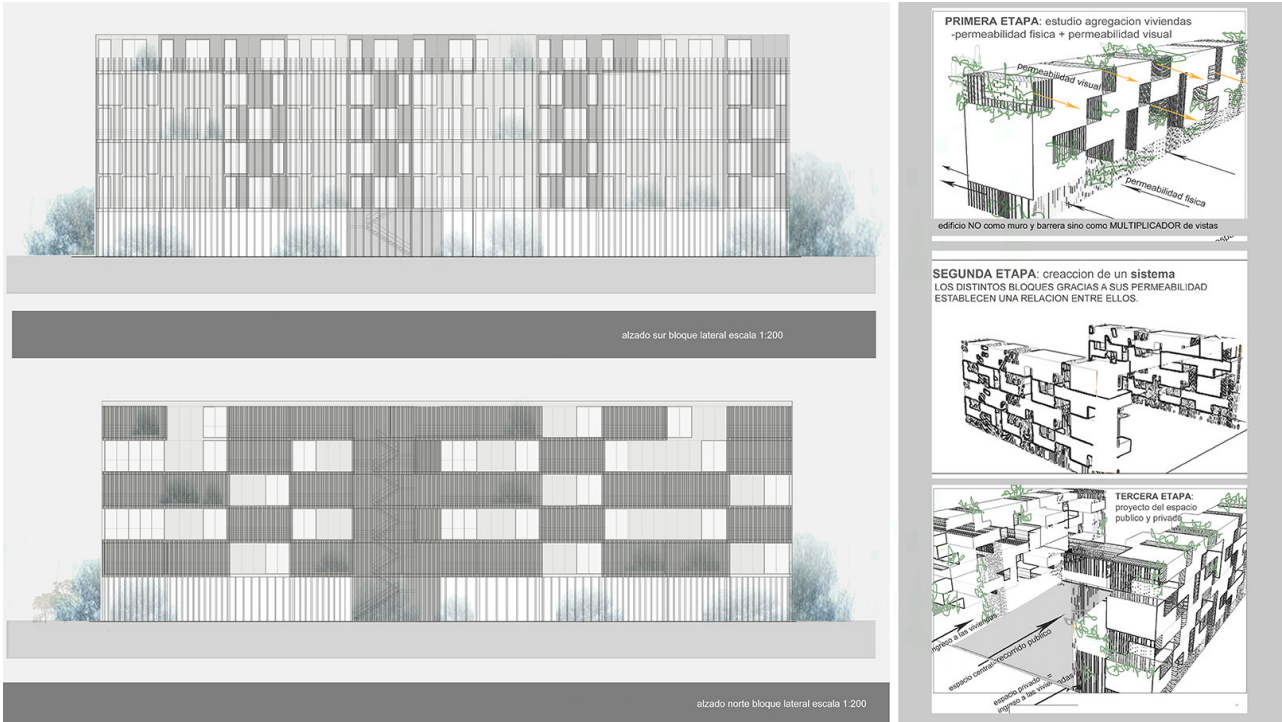

per conferire una chiave grafica univoca alla rappresentazione si è scelto di rappresentare le persone sottoforma di sagome con il fine di evitare che si confondessero troppo con il progetto architettonico retrostante. Particolarmente esplicita risulta la volontà di porre l'individuo al centro del progetto. L'immagine grafica di sintesi inoltre, come elemento centrale, riporta il verde che è il principale e indiscusso protagonista. La rappresentazione ha un ruolo di fondamentale importanza, e cioè quello di comunicare non solo il progetto architettonico

ma anche e soprattutto la sua essenza e quindi il suo intrinseco potenziale (fig. I0).

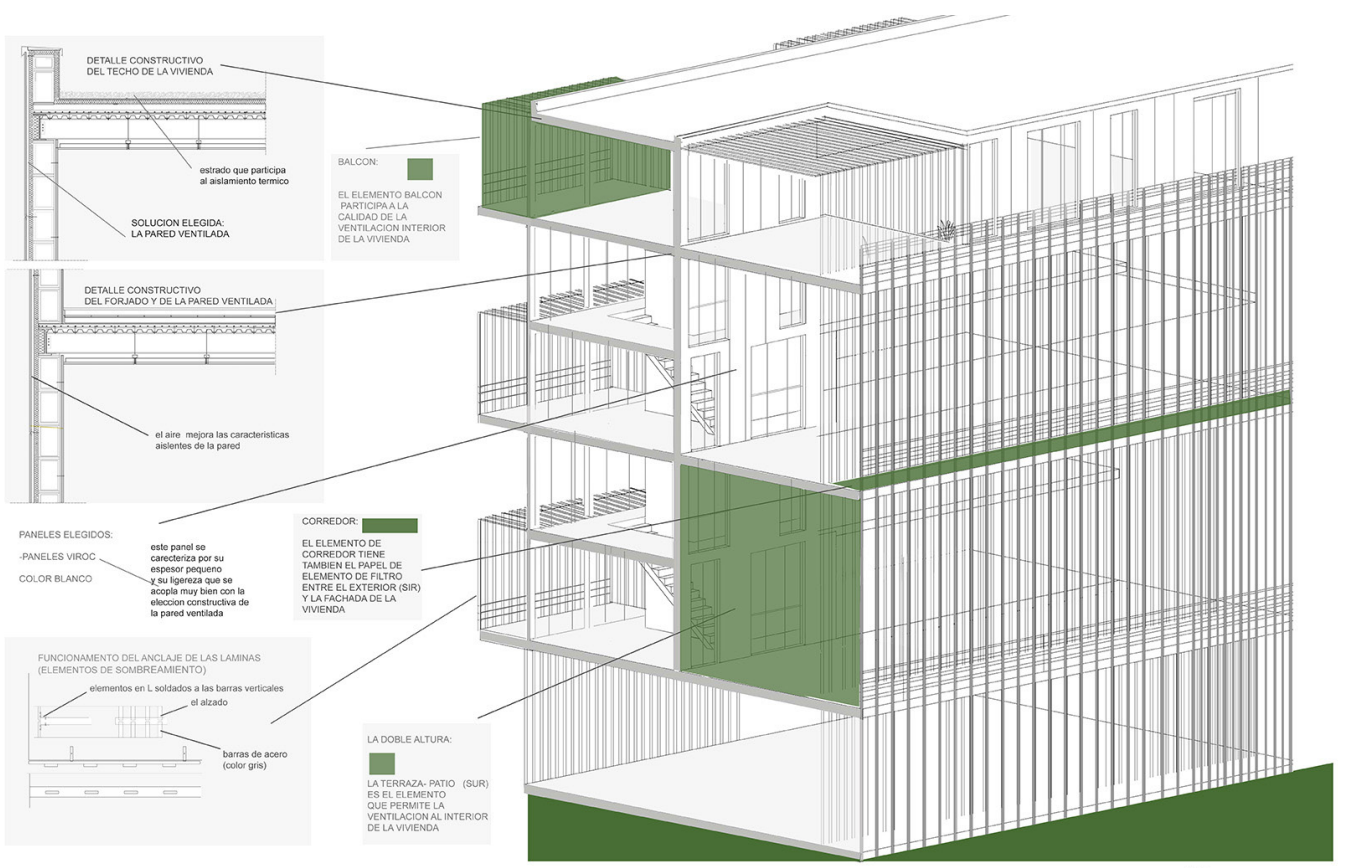

Fig. 9. Rappresentazione assonometrica dell'edificio grafica G. Pettoello). 


\section{Conclusioni e obiettivi futuri}

I risultati raggiunti con il presente lavoro sono la produzione di elaborati grafici in grado di veicolare a un ampio pubblico eterogeneo un progetto di architettura e in particolare la riqualificazione di uno spazio periferico in disuso. Obiettivo futuro è quello di occuparsi anche di ulteriori aree degradate e periferiche, non solo circostanti la città di Valencia, ma anche situate in atri centri urbani. Sarà infatti possibile, attraverso la produzione di illustrazioni grafiche, 'manifesti di progetto', rappresentare la possibile trasformazione di aree periferiche di ulteriori città e quindi realizzare innumerevoli scenari di trasformazione. La rappresentazione grafica ha il grande valore di poter parlare a tutti contemporaneamente senza bisogno di parole. Attraverso il disegno e quindi, più in generale attraverso l'illustrazione, si ha la capacità di 'rappresentale l'invisibile'. Attraverso la rappresentazione è possibile infatti esplicitare un'idea, un pensiero o un'intuizione. L'obiettivo della presente ricerca è proprio quello di mostrare l'illimitato potenziale dell'illustrazione grafica nel settore della progettazione architettonica. In un'epoca 'fluida' l'immagine risulta una modalità particolarmente efficace per poter comunicare in modo estremamente sintetico e incisivo un"idea. Ogni progettista, architetto e designer ha la responsabilità di occuparsi di questo ambito così ricco e complesso tenendo sempre conto di quanto l'illustrazione grafica, oltre che prodotto finale, è anche e soprattutto veicolo di comunicazione. "Soltanto disegnandola una cosa si può dire

Fig. I0. Illustrazione grafica di sintesi: il Manifesto di progetto (elaborazion grafica G. Pettoello)

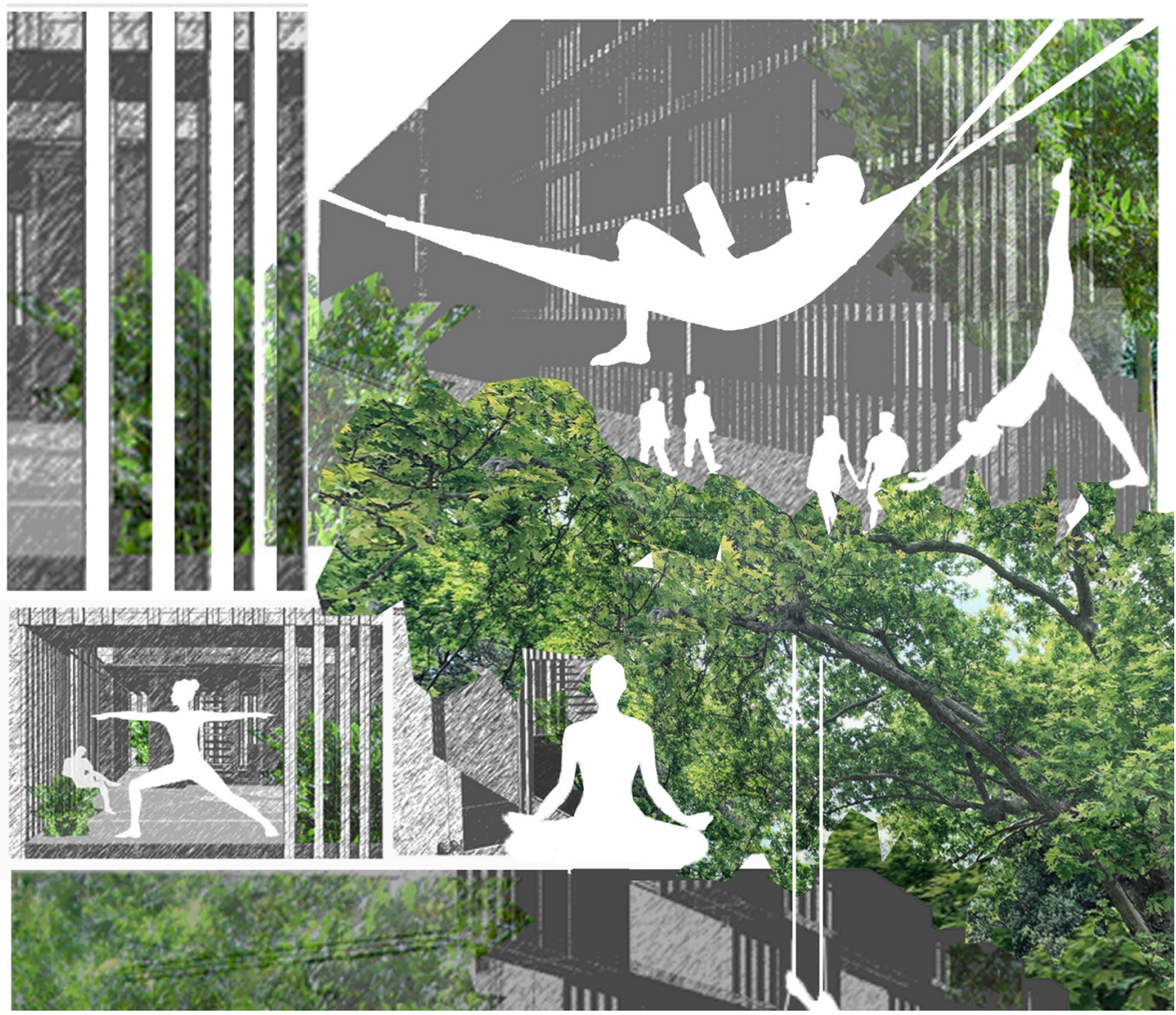

Note

[l] Enciclopedia Treccani:Tratto da: <http://www.treccani.it/enciclopedia/disegno> (consultato il 25 gennaio 202I),

[2] Jean- Dominique Ingres, Pensieri, 1870 
[3] Stefano Boeri. Tratto da: <https://youmanist.it/categories/architettura-design/stefano-boeri> (consultato il 24 gennaio $2021)$.

[4] Tratto da <https:/li.pinimg.com/736x/bc/db/47/bcdb47592c I79b3c5ba7| f8a222 I7cl6.jpg> (consultato il 24 gennaio 2021).

[5] Tratto da: <http://afasiaarchzine.com/20 | 3/03/sou-fujimoto-architects- I |/> (consultato il 23 gennaio 202 I).

[6] <https://www.bloglovin.com/blogs/arch-daily-375859/tsinghua-ocean-center-open-architecture-5520999789> (consultato il 23 gennaio 2021).

[7] Giuseppe Di Napoli, Che cos’è un disegno e perché si disegna. Tratto da: <http:77journals-openedition.org/estetica/ 1955> (consultato il 25 gennaio 202I).

\section{Riferimenti bibliografici}

Boeri S. (2015). Un bosco verticale. Libretto di istruzioni per il prototipo di una città foresta. Milano: Corraini editore.

Cardelus C. (2019). Case sostenibili. Luogo edizione: Loft Media publishing.

Jodido P. (20 I 8). Green Architecture. Edilizia italiana, spagnola e portoghese. Colonia:Taschen editore.

Manovich L. (2008). II linguaggio dei nuovi media. Milano: Olivares.

Rubini L., Sangiorgio S., Le Noci C. (2016). II nuovo edificio green. Soluzioni per il benessere abitativo e l'efficienza energetica. Milano: Hoepli.

Sacchi L., Unali M. (2003). Architettura e cultura digitale. Milano: Skira.

\section{Autore}

Gliulia Pettoello, Sapienza Università di Roma, giulia.pettoello@uniromal .it

Per citare questo capitolo: Pettoello Giulia (2021). Quando l'architettura è illustrazione: la comunicazione del progetto/When architecture is illustration: communicating the project. n Arena A., Arena M., Mediati D., Raffa P. (a cura di). Connettere. Un disegno per annodare e tessere. Linguaggi Distanze Tecnologie. Atti del $42^{\circ}$ Convegno Internazionale dei Docenti delle Discipline della Rappresentazione/Connecting. Drawing for weaving relationship. Languages Distances Technologies. Proceedings of the $42^{\text {th }}$ International Conference of Representation Disciplines Teachers. Milano: FrancoAngeli, pp. 995-1012. 


\title{
When Architecture is Illustration: Communicating the Project
}

\author{
Giulia Pettoello
}

Abstract

This article investigates the unlimited potential of graphical illustration in the field of architecture. Indeed, communication of the project constitutes a continuously evolving aspect. The case study presented in this research regards design related to a peripheral and degraded area in the Fuente de Sal Luis neighbourhood of Valencia, Spain. In particular, the intervention deals with the design of collective housing. The challenge is to design an architectural 'complex' that is collective and social, characterized by heightened spatial quality. In fact, the function should not, as too often happens, compromise the living quality. Greenery, common spaces, and double-level patios intersect to create a 'living building'. The objective of the present work is to create a synthetic illustration that can involve the user. The role of graphical representation is essential for ensuring that the designer's idea can be transmitted in order to facilitate understanding. The desire is therefore to make the narration more efficient not only for technicians in the sector, but especially for a non-specialized public: citizens or potential future investors. The summary illustration acts as a connection between the 'imagined space' and the 'built space' and therefore between the idea and later realization. The graphical illustration therefore becomes essential language for investigating, talking about, and spreading the intrinsic essence of the building.

Keywords

illustration. architecture, city, drawing, project.
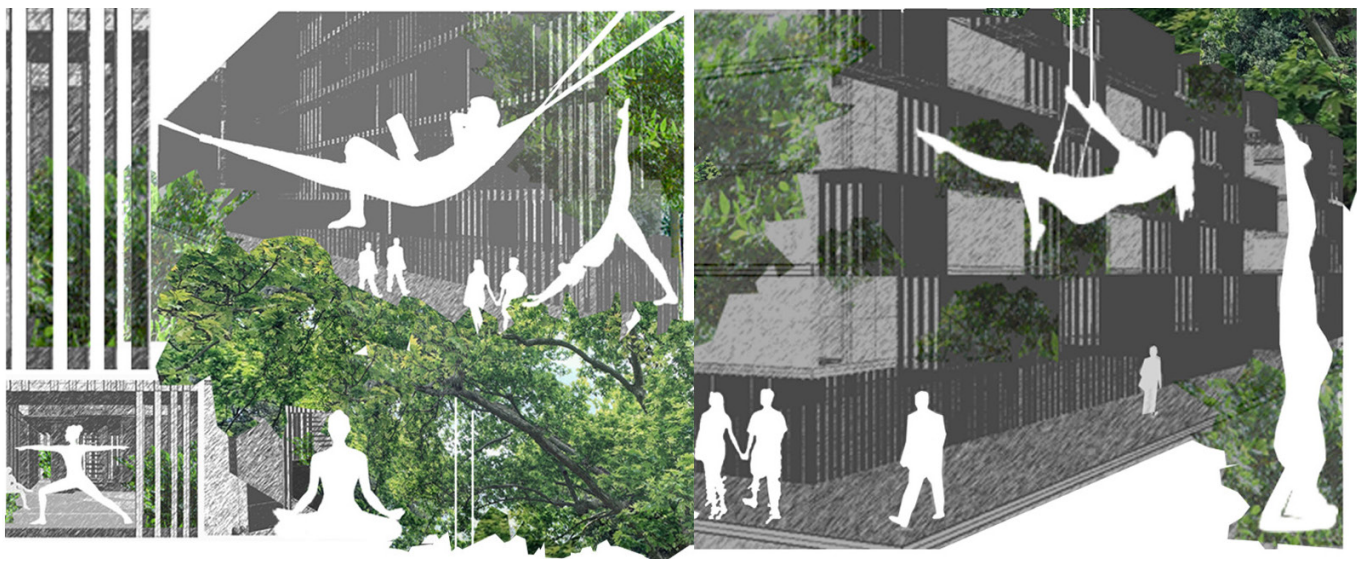


\section{Introduction}

Traditional drawing, digital drawing, integrated graphical representation, digital collage are some of the innumerable instruments and methods used to create a graphical illustration. "The noun disegno [drawing] defines any image produced with a line made with tools such as pencil, pen, paintbrush, metallic tip, or sanguine. It comes from the verb disegnare [to draw], with its roots in the Latin designare, a term that may be translated in many ways: sketch, hint, allude, delimit, trace, note, mark, imitate, choose, order, display. These are meanings that indicate both the simple sketch of something (a figure or landscape) and the precise notation of its characteristics (such as its volume, colours, reflections of light on the surface)" [I]. This definition immediately shows how drawings, and graphical illustration in general, are complex and also extremely powerful. A drawing should therefore be intended not as a final result, but as a tool to translate the thought on paper. The connection between drawings and thought is extremely strong. In this article, drawings are interpreted from different points of view: as a tool for the project, therefore entailing the creation of preliminary sketches and 2D technical drawings; as a tool for verification, therefore entailing 3D volumetric representations; and finally, as a tool for communication, entailing the creation of global summary images. "It is always necessary to draw, drawing with the eyes if one cannot draw with the pencil. As long as you do not advance reflection with practice, you will never do anything truly good" [2].

Specifically, the research is translated into the realization of different graphical illustrations that correspond to the different phases of work: project sketches, plans/distribution diagrams, synthetic volumetric representations related to the aggregation of residential units, 2D representations of the internal distribution, elevations and sections in 1:200 scale, axonometric drawings of the whole, and a summary illustration of the project. Drawings are therefore essential throughout the creative process, both as a design tool and as a means to communicate the project idea. The objective of the present work is to create a synthetic illustration that can involve the user. Indeed, this illustration shows views of the project in which the user is inserted as the key player. Some elevations are made only at human height, for example, precisely to allow users to 'imagine' themselves within the
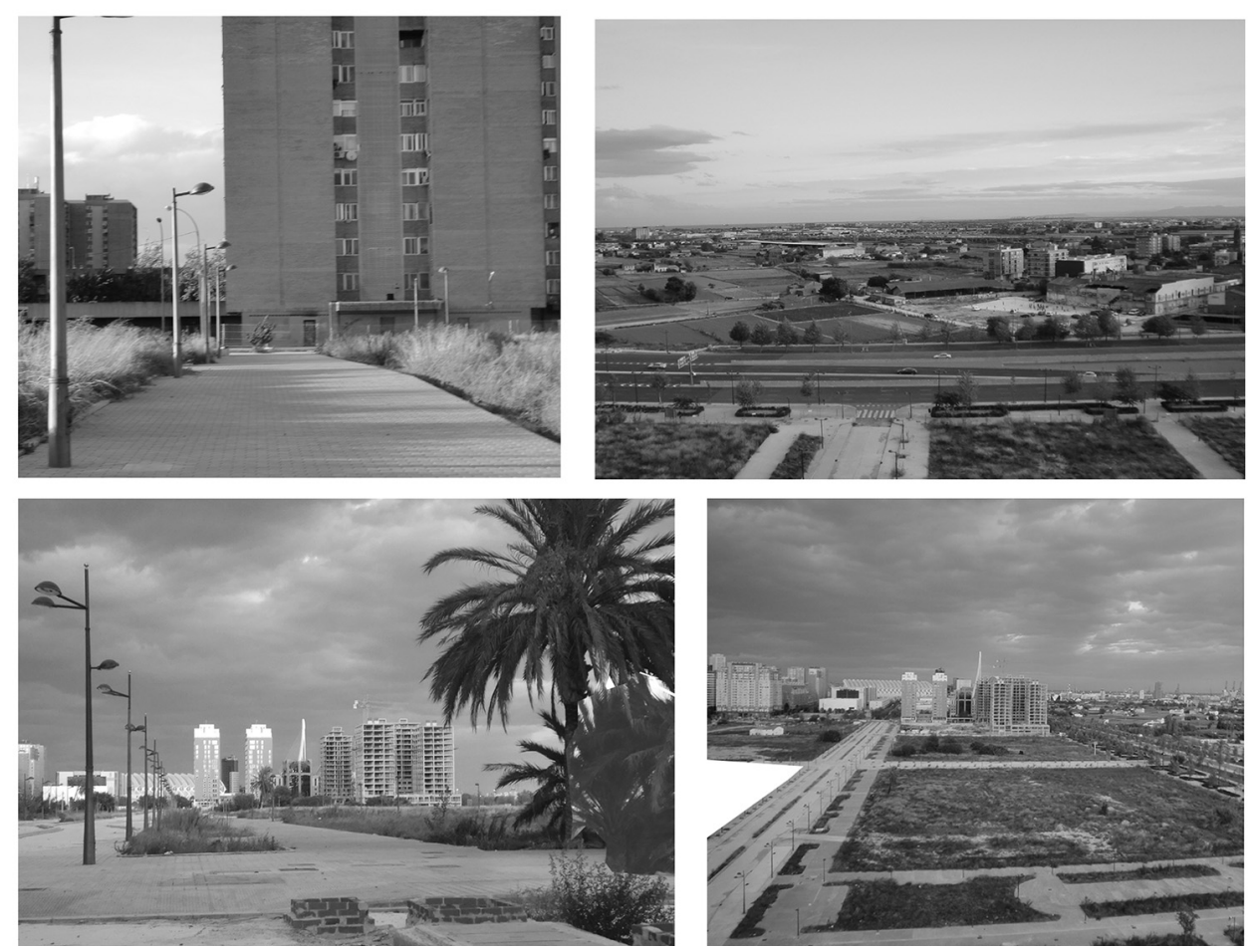
designed space. A variety of techniques are used: traditional drawings coexist with digital representations.

The steps in the project entailed: identification of residential units that build the urban façade through repetition and modularity; definition of the different systems of gathering in residential units; and, finally, synthetic representation. The objective of the architectural project is to create a 'filter' building characterized by low visual impact and, especially, by the presence of vegetation within. The primary feature of the present work is twofold: integrating greenery within the building itself and freeing the land as much as possible, transforming it into open common area and a green zone.
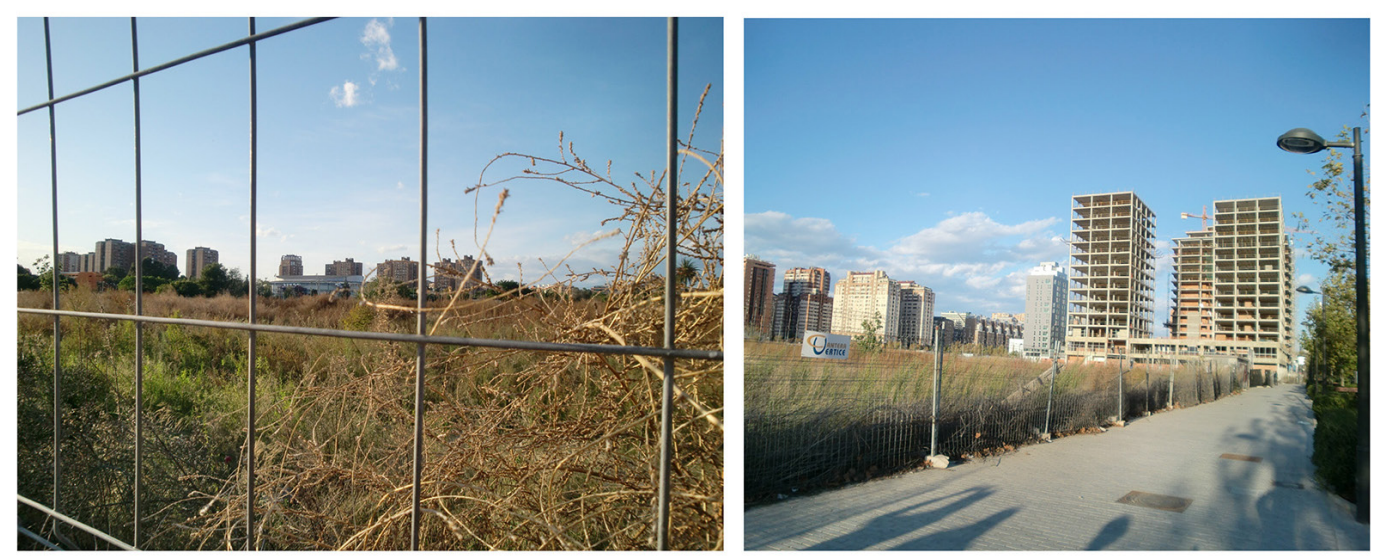

\section{State of the Art}

Among the different case studies analysed, the projects by the architect Stefano Boeri are important. "With respect to this type of architecture, a true international trend towards Vertical Foresting has begun" [3]. In particular, the most important illustrations in the project include numerous representations in which the green 'element' is the main character. Indeed, the architectural complex always lies in the background. This graphical choice is particularly incisive and perfectly expresses the essence of the project.

Another particularly important case study is Tbl Msc Komplex [4] by Clark Adam Ter, which also relates to 'green architecture'. The chromatic choice that unites the different representations of the project is interesting. The architecture is always represented in grey scale to emphasize the green element, which is also the key player here. Overall views and detailed views are created, but views from the human perspective predominate, making the illustrations 'communicate' better. An interesting contrast is created between the more rigorous architectural volumes and surfaces and the more 'fluid' natural elements. Another work analysed comes from the Sou Fujimoto Architects group [5] In this case as well, the chromatic palette of all the representations relies on the grey scale for the architecture and green for all natural elements. In addition to the use of a single colour for the architecture, the lightness of the mark and the introduction of shadows -clean and strong- are also important for highlighting the construction. The illustrations are therefore elegant and refined, but also particularly incisive.

Another example is the graphical method chosen to represent the project Gallery of Tsinghua Ocean Center [6]. In this case, very simple axonometric diagrams explain the entire design process in just a few steps.

All the case studies mentioned above are particularly important in that they represent the wide range of topics related to greenery in architecture. The present article inves- 
tigates the different means -traditional and integrated- necessary to illustrate 'green architecture', and in particular, the case study situated in the Spanish neighbourhood of

Fuente San Luis.
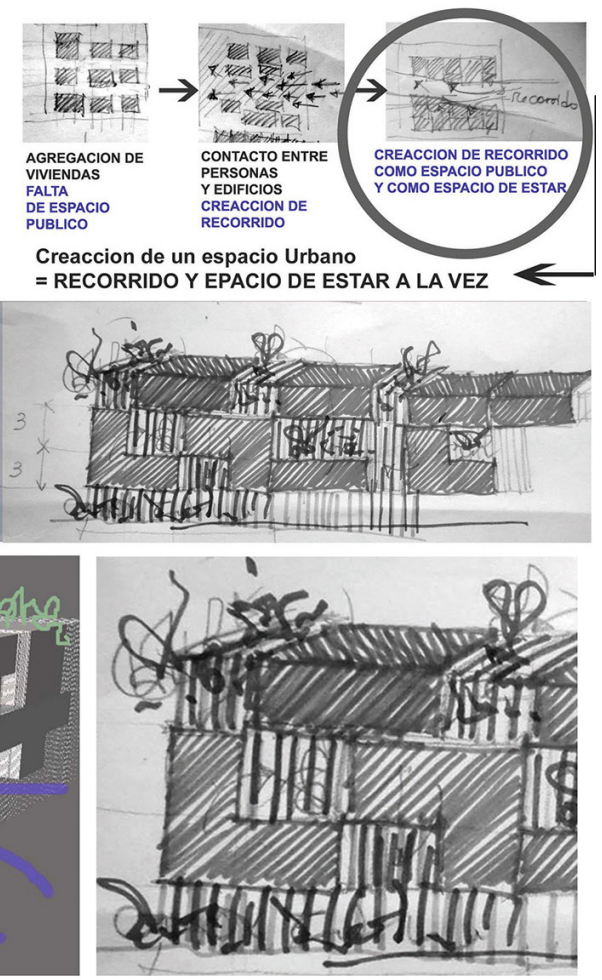
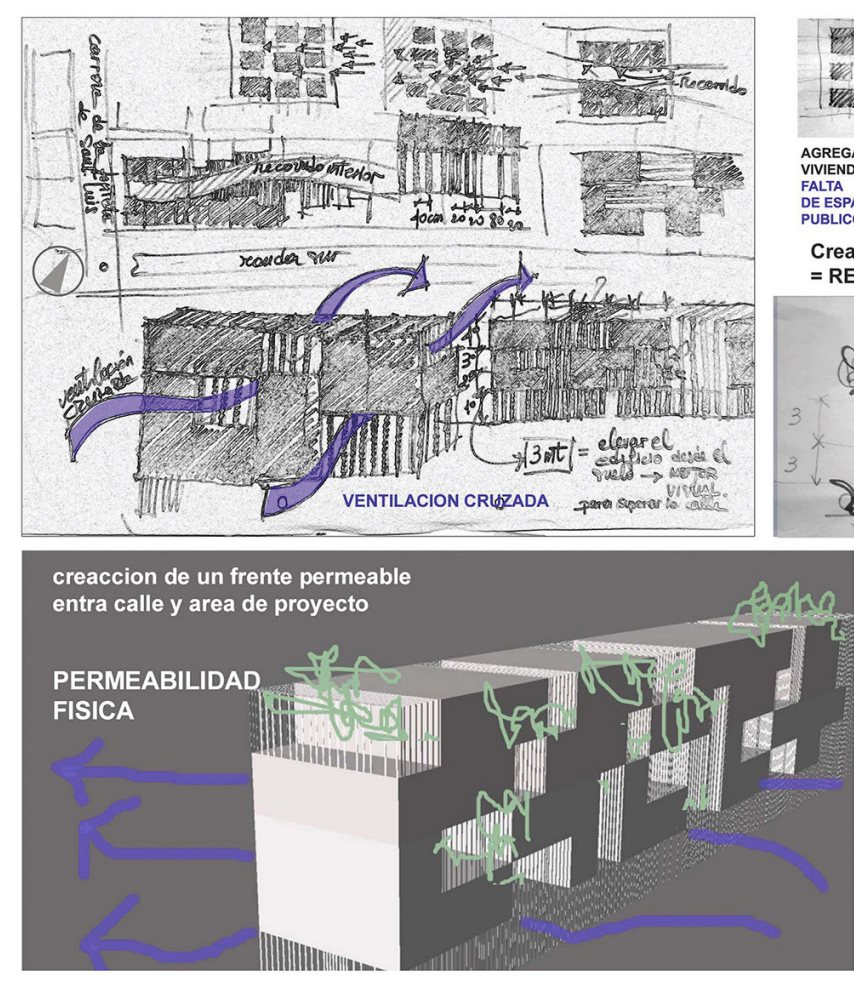

Fig. 3. Definition of the about the study sketches (graphic elaboration by G. Pettoello).

\section{Design Phases}

This work was carried out in a series of interconnected phases. The first regarded an inspection of the area under study. This is the neighbourhood of Fuente San Luis (fig. I), situated on the outskirts of Valencia, Spain. This phase also entailed a photographic campaign of the parcel under study (fig. 2). The surrounding buildings were very useful for the photographic survey. In fact, photos were taken from the top floors of these buildings to better understand the various possible 'visuals' to utilize in the design phase. From the survey, the poor architectural quality of the buildings surrounding the project was made evident: buildings of I0- I 5 storeys lacking exterior space and all very similar to each other. Another essential aspect that became clear through the survey was the lack of a furnished green area, which could be created very easily without a large monetary investment.

The second phase regarded the concept design. In particular, by making preliminary sketches and graphical representations by hand, it was possible to delineate the project idea (fig. 3). The third phase involved the creation of 3D studio drawings (fig. 4). In this phase, the creation of schematic solids was essential. Indeed, in contrast to the "physical maquette', the 'digital maquette' has the great advantage that it can be constantly assembled and disassembled in real time simply by making back-ups of the original volume. This approach, which is particularly flexible and quick, allowed the initial project idea to be verified immediately. The insertion of 'modular elements' with different shapes and sizes made it possible to simultaneously achieve a very lively effect that could also be easily executed, thereby avoiding particularly personalized elements that would require large sums 
of money to build. Since this is a 'public' architectural project, essential aspects to consider are always optimization and economic sustainability.

The fourth phase entailed the creation of schematic representations to verify the volumes (fig. 5) and the fifth phase regarded the CAD creation of 2D representations of the project in plan, elevation, and section (figs. 6-9). In this phase, axonometric drawings were also made to represent the distribution of outdoor spaces (fig. I0). The last phase entailed the creation of the summary graphical image: a project poster, which is described in detail below.

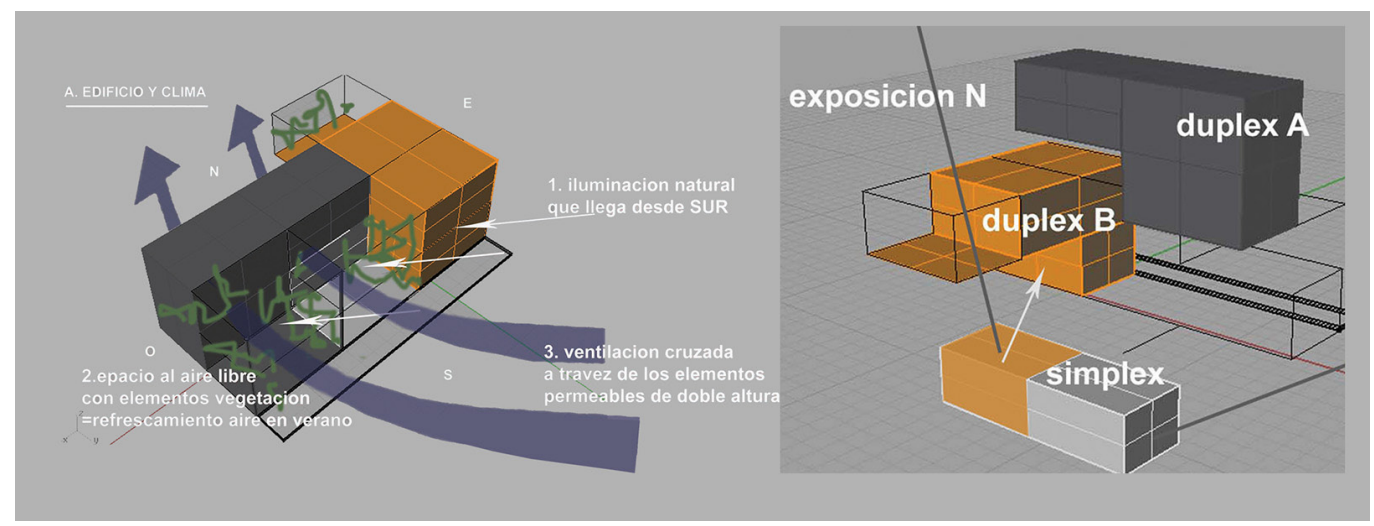

\section{Architectural graphical illustration}

The challenge was to use a single unique image, the 'project poster' to communicate the power and value of the entire project. The first necessary feature of this representation is a great capacity to synthesize. In fact, it should communicate, transmit, and clarify multiple aspects while maintaining an extremely simple expressive clarity. Among the different aspects to be depicted, the most difficult is surely the 'intangible' value that the proposed architectural project brings to the place and the community. Because the value is intangible, its 'graphical translation' is particularly complex. In this case, the 'added value' of the project is precisely the possibility of carving out green spaces, both public and private, to improve the quality of life of the future residents.

Particular attention focuses on the design of small outdoor green spaces designed for each residential unit. The outdoor spaces vary in type and size, but they all add quality to the individual residence. The different green spaces created include the following major types: balconies, dual-level patios, partially covered terraces, and uncovered terraces. To enrich the housing, the spaces as designed allow numerous recreational and leisure activities to be held within, including: reading, yoga, heliotherapy, and the cultivation of plants and small gardens. This is precisely the preponderant element in the summary graphical illustration, the project poster'. The decision was made to show people intent on practicing different hobbies, from the most common to the most unusual, precisely to emphasize this aspect of the project. Instead of showing plans, sections, and elevations very technical drawings that are obviously essential in the planning phase, but ill suited to communication -the decision was made to 'build' a representation that could be read by everyone- technicians, but also and especially lay people, for example, citizens or possible stakeholders and financiers of the project. In addition, to create a more dynamic representation, the choice was made to select different 'views', such as perspectives of the whole and details to create a composition that better explains the entire project. Nevertheless, to confer a unique graphical key on the representation, the people were represented as silhouettes to avoid too much confusion with the 
Fig. 5. Graphical shemes about the project

communication (graphic elaboration by $\mathrm{G}$. Pettoello).

Fig. 6. Planimetry of the project (graphic elaboration by G. Pettoello)

Fig. 7. 2D CAD representation about building's layouts (graphic elaboration by G. Pettoello).
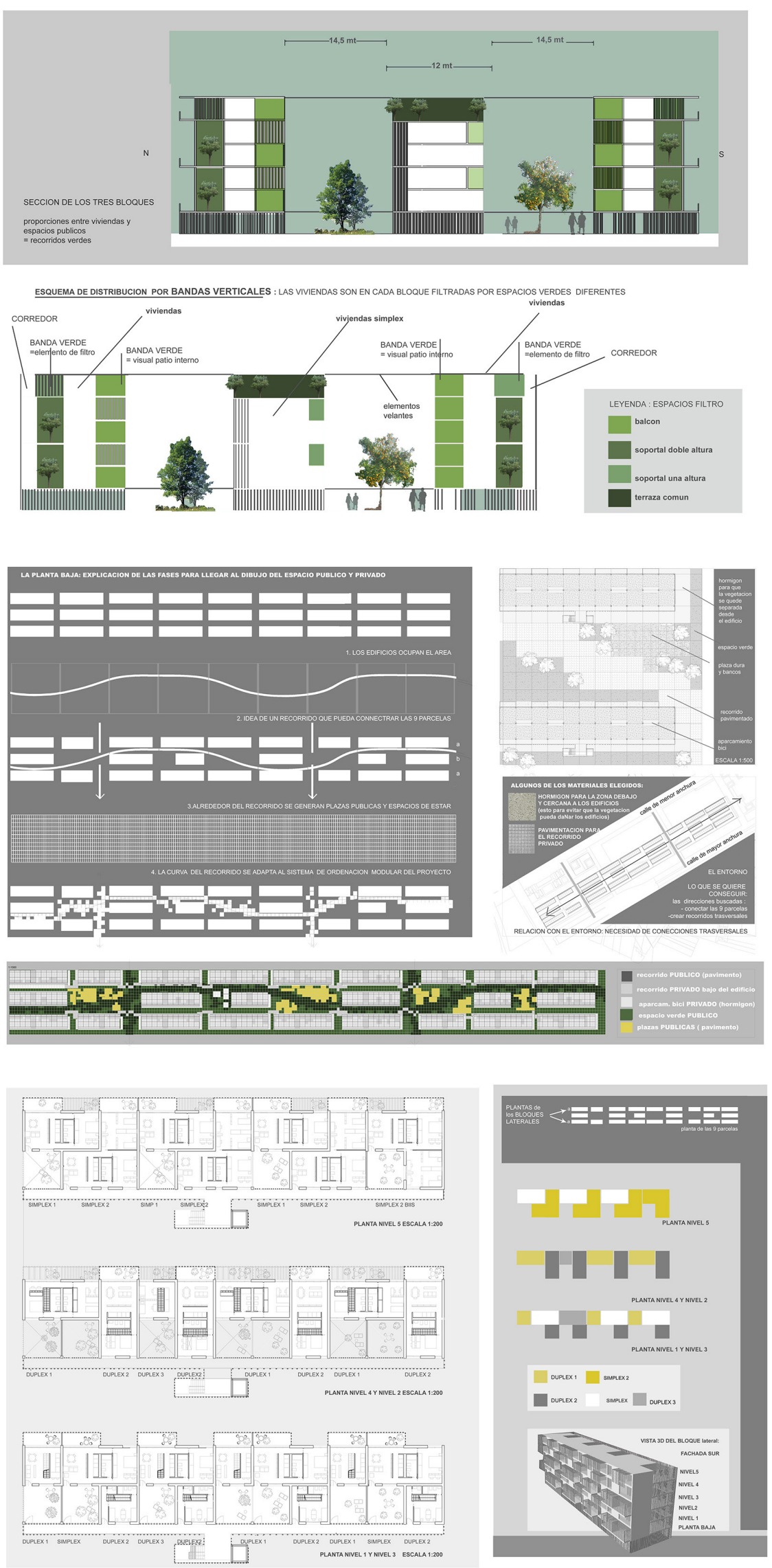
Fig. 8. 2D CAD representation about building's façades (graphic elaboration by $\mathrm{G}$. Pettoello).
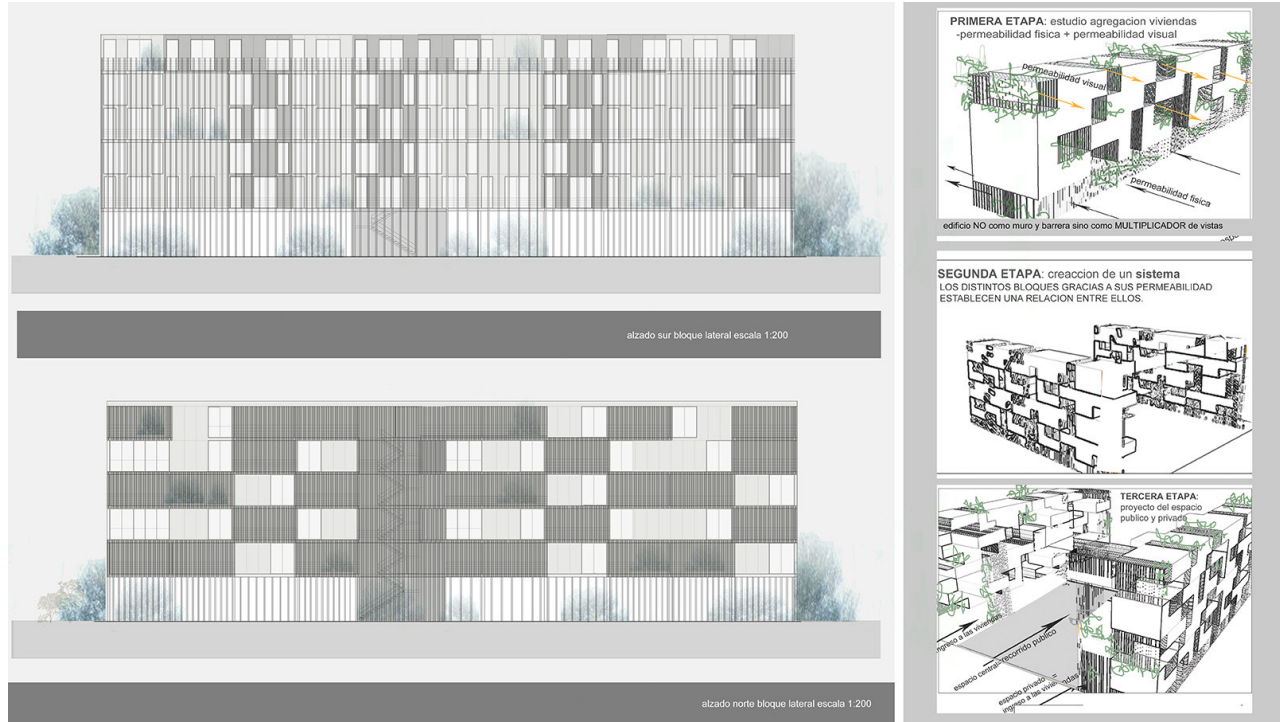

underlying architectural project. Particularly clear is the desire to place the individual at the centre of the project. As a central element, the summary graphical image also displays the greenery, which is the primary, indisputable protagonist. This representation plays a fundamental role, that is, communicating not only the architectural project, but also and especially its essence and therefore its intrinsic potential (fig. I I).

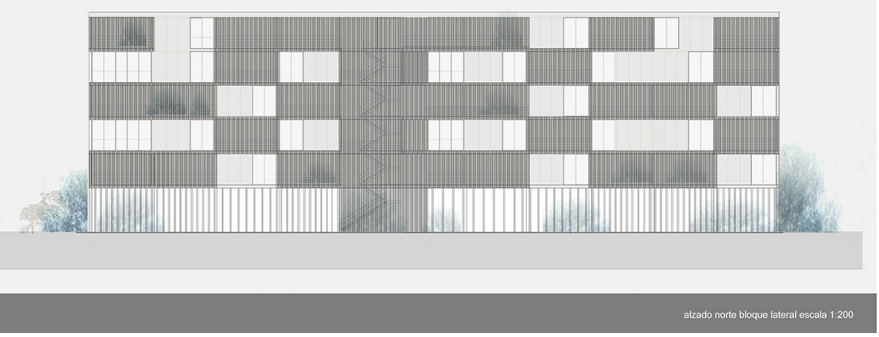

Fig. 9. Axonometric

representation about

the architectural project
(graphic elaboration by $\mathrm{G}$. Pettoello). 


\section{Conclusion and Future Objectives}

The results of the present work are graphical drawings capable of transmitting an architectural project to a broad, non-uniform public, and the regeneration of a disused peripheral space. A future objective is to also address other degraded and peripheral areas, not only around the city of Valencia, but in other urban centres as well. In fact, by producing graphical illustrations -'project posters'- it will be possible to represent the possible transformation of peripheral areas in other cities and therefore create numerous scenarios of transformation. Graphical representation holds great value in that it speaks to everyone at once without the need for words. Through drawings, and illustrations more in general, one can 'represent the invisible'. Indeed, representation enables an idea, thought, or intuition to be clarified. The objective of the present research is precisely to show the unlimited potential of graphical illustration in the sector of architectural design. In a 'fluid' era, images are a particularly effective way of communicating an idea extremely synthetically and incisively. Each planner, architect, and designer has a responsibility to address such a rich and complex area, always considering how much a graphical illustration, in addition to a final product, is also and especially a vehicle for communication. "Only by drawing something can we say we have really seen it" [7].

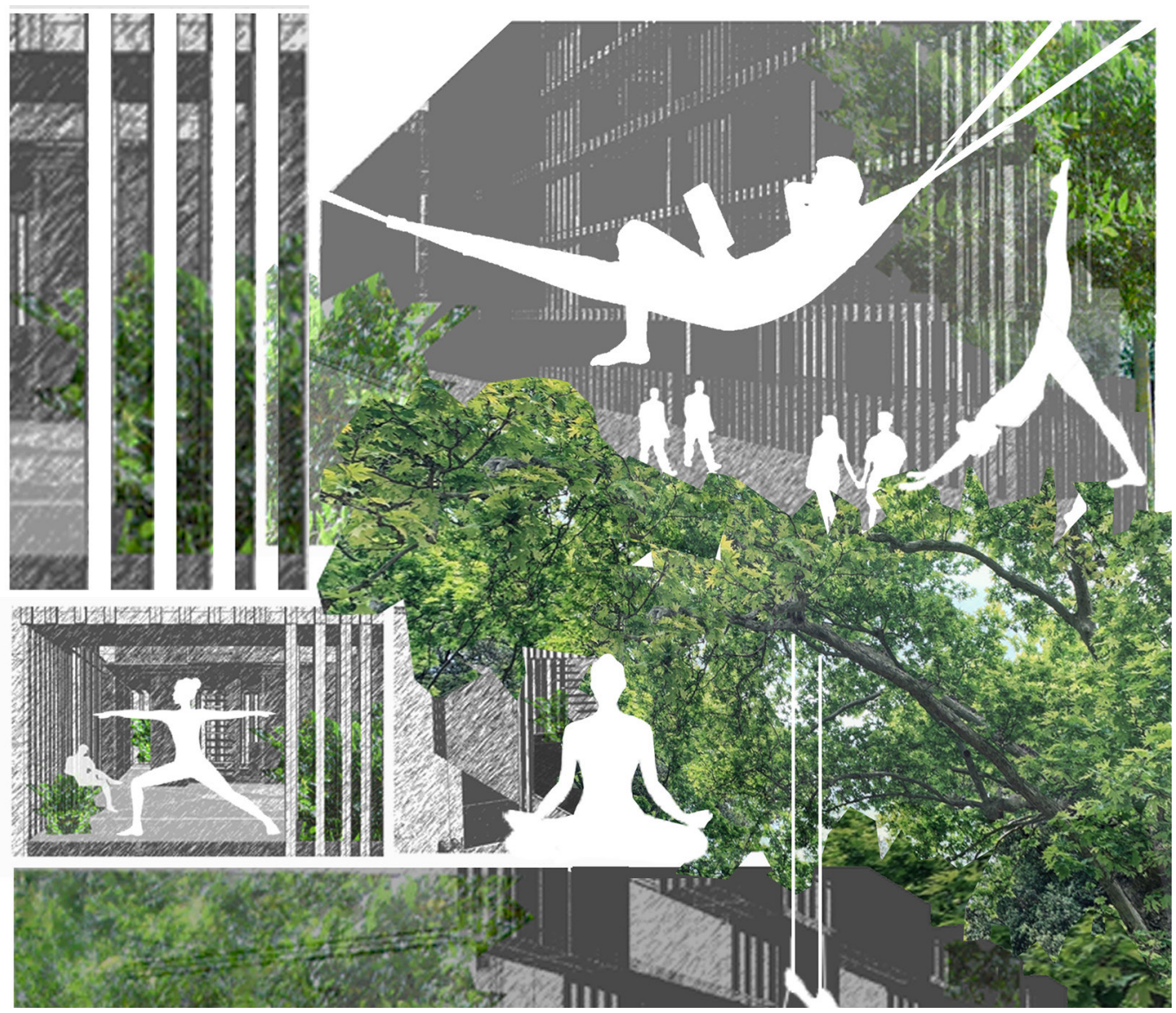

Notes

[I] Enciclopedia Treccani: <http://www.treccani.it/enciclopedia/disegno> (accessed 202I, January 21).

[2] Jean-Dominique Ingres, Pensieri, 1870. 
[3] Stefano Boeri: <https://youmanist.it/categories/architettura-design/stefano-boeri> (accessed 2021, January 24).

[4] See: <https://i.pinimg.com/736x/bc/db/47/bcdb47592c/79b3c5ba7/f8a22217c|6.jpg> (accessed 2021, January 24).

[5] See: <http://afasiaarchzine.com/2013/03/sou-fujimoto-architects-I I/> (accessed 202I, January 24).

[6] See: <https://www.bloglovin.com/blogs/arch-daily-375859/tsinghua-ocean-center-open-architecture-5520999789> (accessed 2021, January 24).

[7] Giuseppe Di Napoli, Che cos'è un disegno e perché si disegna: <http:77journals-openedition.org/estetica/l955> (accessed 2021, January 24).

\section{References}

Boeri S. (20I5). Un bosco verticale. Libretto di istruzioni per il prototipo di una città foresta. Milano: Corraini editore.

Cardelus C. (2019). Case sostenibili. Luogo edizione: Loft Media publishing.

Jodido P. (20 I 8). Green Architecture. Edilizia italiana, spagnola e portoghese. Colonia:Taschen editore.

Manovich L. (2008). Il linguaggio dei nuovi media. Milano: Olivares.

Rubini L., Sangiorgio S., Le Noci C. (2016). II nuovo edificio green. Soluzioni per il benessere abitativo e l'efficienza energetica. Milano: Hoepli.

Sacchi L., Unali M. (2003). Architettura e cultura digitale. Milano: Skira.

\section{Author}

Gliulia Pettoello, Sapienza Università di Roma, giulia.pettoello@uniromal.it

To cite this chapter. Pettoello Giulia (202I). Quando l'architettura è illustrazione: la comunicazione del progetto/When architecture is illustration: communicating the project. In Arena A., Arena M., Mediati D., Raffa P. (a cura di). Connettere. Un disegno per annodare e tessere. Linguaggi Distanze Tecnologie. Atti del $42^{\circ}$ Convegno Internazionale dei Docenti delle Discipline della Rappresentazione/Connecting. Drawing for weaving relationship. Languages Distances Technologies. Proceedings of the $42^{\text {th }}$ International Conference of Representation Disciplines Teachers. Milano: FrancoAngeli, pp. 995-1012 